\title{
Editorial: Disarmament and Development - the International Context
}

\author{
Robin Luckham
}

'A Klee painting named 'Angelus Novus' shows an angel looking as though he is about to move away from something he is fixedly contemplating. His eyes are staring, his mouth is open, his wings are spread. This is how one pictures the angel of history. His face is turned towards the past. Where we perceive a chain of events, he sees one single catastrophe which keeps piling wreckage upon wreckage and hurls it in front of his feet. The angel would like to stay, awaken the dead, and make whole what has been smashed. But a storm is blowing from Paradise; it has got caught in his wings with such violence that the angel can no longer close them. This storm irresistably propels him into the future to which his back is turned, while the pile of debris before him grows skyward. This storm is what we call progress.' Walter Benjamin, Illuminations, Schocken Paperbacks, New York, 1969.

'A world in which politics is replaced by arsenals and economy by finance is simply a world in danger.' Raul Alfonsin, President of Argentina, quoted in SIPRI, 1985: 445 .

Like the angel of history we all wish we could stretch back to repair the past. Still more, we would like to turn our heads forward to avert the catastrophes of the future. Five years ago, when introducing the Report of the Independent Commission on International Development Issues, North-South: a Programme for Survival, Willy Brandt had this to say to the international community:

We see a world in which poverty and hunger still prevail in many huge regions; in which resources are squandered without consideration of their renewal; and where a destructive capacity has been accumulated to blow up our planet several times over. [Hence this] . . globalisation of dangers and challenges - war, chaos, self-destruction - calls for a domestic policy which goes much beyond parochial or even national items. Yet this is happening at a snail's pace. A rather defensive pragmatism still prevails, when what we need are new perspectives and bold leadership ... The 'international community' is still too cut off from the experience of ordinary people and vice versa.

In spite of these warnings and many others like it, the snail's pace has become disorderly retreat. At the start of the 1980s the world economy slid into a new phase of recession, from which recovery is still uncertain. Furthermore, this deterioration and its effects on the developing countries could probably have been avoided, being 'explained in part by past policy choices as well as underlying economic and social conditions. In an interdependent world economy, growth in the developing countries is significantly affected by what happens in industrial countries' [World Bank 1984: 12].

Table 1

NATO Military Expenditure, 1950-84

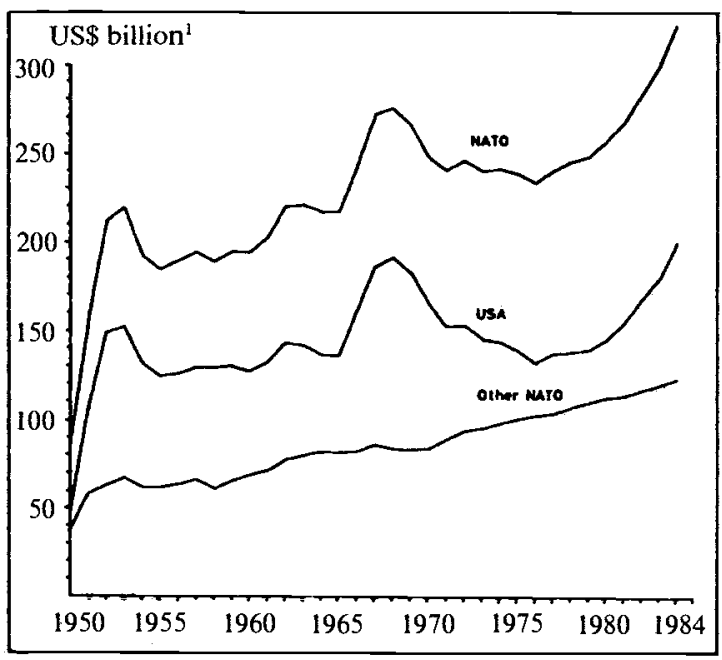

${ }^{1}$ At 1980 prices and exchange-rates.

Source: SIPRI [1985: 229] 
Recession has coincided with a marked acceleration in the global arms race. After a period of decline (both in constant price values and relative to GNP) the military spending of the major Western powers, especially the United States, has increased sharply (Table 1). Trends in the socialist bloc are less easy to discern because of the absence of reliable official figures, though most sources are in agreement that steady increases have occurred in the Soviet Union [SIPRI 1985: 251] contrasting with the more cyclical behaviour of the United States. The deployment in Europe of Soviet SS20 and American Cruise and Pershing missiles has gone ahead. Having broken down altogether at the end of 1983, negotiations concerning nuclear weapons have (since January 1985) resumed; though for the present they remain little more than 'talks about talks', being stalled over the United States' Strategic Defence Initiative for defence against ballistic missiles ('Star Wars'). Meanwhile there has been no sign of a resumption of the talks between the two superpowers concerning the limitation of conventional arms transfers to developing countries or of those about military restraints in the Indian Ocean, broken off in the late 1970 s.

Instead, the major military powers (France and the UK as well as the superpowers) have built up their intervention forces, increased global naval deployments and negotiated new military facilities in the Third World, incorporating new areas within the strategic terrain of the new Cold War. The possibility of horizontal escalation between war theatres in Europe and the Third World is often discussed by strategic analysts. The 1978 fictional simulation of the Third World War by General Sir John Hackett and a team of military experts [Hackett 1978] describes how a nuclear confrontation between the powers in Europe in 1985 is precipitated by conflicts in the Middle East and Southern Africa, along with unrest in Poland and a Soviet invasion of Yugoslavia - a reconstruction that was supplemented in 1982 to cover events in Central America and the Far East [Hackett 1983]. Such scenarios are by no means confined to works of fiction. They are widely used by Northern governments and military planners to argue for closer involvement in Third World security questions. Conversely it is often argued that it is precisely the transfer of EastWest tensions to the South that establishes a deadly connection between Third World conflict and global insecurity [see for example, Nincic 1985 and Tamas Szentes' article in this issue of the IDS Bulletin].

These developments have reinforced a widening disparity between global power relations and trends in the international economy. The long run decline of the US economy relative to Europe, Japan and the NICs [analysed in more detail in two recent issues of the IDS Bulletin: IDS 1985a and b], led to the breakdown of the
Bretton Woods system and ushered in a multipolar and altogether more anarchic international economic regime. In contrast, however, control over strategic relationships remains where it has been since the late 1940 s - firmly in the hands of the superpowers. Indeed this control has been further consolidated by the Cold War. It is epitomised in the current Geneva 'umbrella' negotiations between the USA and the Soviet Union. One interpretation of the Strategic Defence Initiative is that it is as much aimed at reasserting the US's global power as at changing the strategic relationship with the Soviet Union.

This disparity between a bipolar military order and a multipolar economic order has reinforced the superpowers' determination to maintain their strategic duopoly. In both the USA and the Soviet Union an interdependence has been established between the military and the non-military sectors of the economy through the respective mechanisms of a market and of a centrally-planned economy. In both, the military and military-related industries are almost the only lines of production in which they have managed to maintain a clear competitive edge. The temptation to sell arms and to use force directly in the Third World is arguably all the stronger.

In turn the transfer of East-West military rivalries to the Third World has affected North-South economic relationships. One place where this is visible is in the aid programmes of the major world powers. The previous trend from bilateral to multilateral assistance has been decisively reversed. The allocation of aid has been increasingly harnessed to economic and military purposes. A recent review of US assistance carried out for the Secretary of State (the first major overall review of US aid policy since 1970) concluded that economic and military assistance must be closely integrated.

Economic growth and rising standards of living are vital to internal stability and external defense. Threats to stability impede economic development and prosperity. Thus ... the future effectiveness of the mutual assistance program rests on the concept that security and growth are mutually reinforcing and that both are fundamental to the advancement of US interests [Commission on Security and Economic Assistance 1983: 2-3].

As for the developing countries themselves, their military spending (see Table 2) has increased more or less continuously over the post-independence era, faster on the whole than that of the industrial North, although the increases tailed off in the early 1980s, when the full impact of the second and more severe phase of the recession made itself felt. The opportunity costs of military spending in terms of development and 


\begin{tabular}{|c|c|c|c|c|c|c|c|c|c|c|c|}
\hline & 1975 & 1976 & 1977 & 1978 & 1979 & 1980 & 1981 & 1982 & 1983 & 1984 & $\begin{array}{r}\text { Share of } \\
\text { World } \\
\text { Total } \\
\%\end{array}$ \\
\hline Industrial market economies & 257,534 & 252,529 & 260,073 & 265,584 & 270,652 & 280,052 & 290,278 & 307,827 & 324,230 & 348,697 & 53.7 \\
\hline Non-market economies & {$[171,972]$} & {$[175,263]$} & {$[176,551]$} & {$[183,312]$} & {$[197,798]$} & {$[189,842]$} & {$[185,448]$} & {$[189,757]$} & {$[191,671]$} & {$[196,133]$} & 30.2 \\
\hline Major oil-exporting countries & 33,352 & 37,450 & {$[36,185]$} & 38,107 & 38,941 & 41,712 & {$[45,143]$} & {$[48,598]$} & {$[44,874]$} & {$[44,988]$} & 6.9 \\
\hline $\begin{array}{l}\text { Rest of the world } \\
\text { With } 1982 \text { per capita GNP: }\end{array}$ & 43,452 & 47,509 & 49,215 & 49,205 & 51,357 & 51,168 & 54,238 & {$[61,862]$} & {$[60,018]$} & {$[57,419]$} & 8.8 \\
\hline$<$ US $\$ 440$ & 6,651 & 7,241 & 6,997 & 7,715 & 8,306 & 8,284 & 8,944 & 9,712 & 10,045 & 9,985 & 1.5 \\
\hline US $\$ 440-1,679$ & 8,979 & 9,323 & 10,193 & 8,547 & 8,541 & 8,101 & 8,493 & 9,385 & 9,415 & 8,635 & 1.3 \\
\hline$>$ US $\$ 1,680$ & 27,822 & 30,945 & 32,025 & 32,943 & 34,510 & 34,783 & 36,801 & 42,765 & 40,558 & 38,799 & 6.0 \\
\hline World total & 507,480 & 514,030 & 523,400 & 537,730 & 560,330 & 564,440 & 576,860 & 609,900 & 622,800 & 649,070 & 100.0 \\
\hline
\end{tabular}

${ }^{1}$ At 1980 prices and exchange rates.

Source: SIPRI [1985: 270]

even more of social welfa re expenditures are high. Yet the fact is that many governments in the South place more emphasis upon national defence than upon development, arguing indeed that the latter is meaningless without the former.

Most developing countries are unable to meet their needs for military equipment from local production, thus being forced into the international arms market where they pay both dearly and frequently for successive generations of weapons systems. The Third World's imports of major weapons approximately doubled in constant price values during the 1960 s and quadrupled in the 1970s, before levelling off and then declining in the early 1980 s (Table 3 ). At the same time, most suppliers have reduced their military grants and insist on payment on commercial terms. Thus in the great majority of cases arms imports have had to be paid for in scarce foreign exchange. The need to earn the latter has far-reaching implications for the structure and management of domestic economies: for example increasing their vulnerability to unstable or declining terms of trade, encouraging short-sighted policies towards non-renewable resources and adding to their international debt burdens. According to the Stockholm Peace Research Institute's estimates, during the period 1972-82 foreign borrowing by nonoil developing countries could have been approximately 20 per cent less each year and their accumulated debts at the end of the period some 15 per cent smaller, had they made no foreign purchases of arms (Table 4).

\section{Table 3}

Trends in Export of Major Weapons to Third World, 1965-84

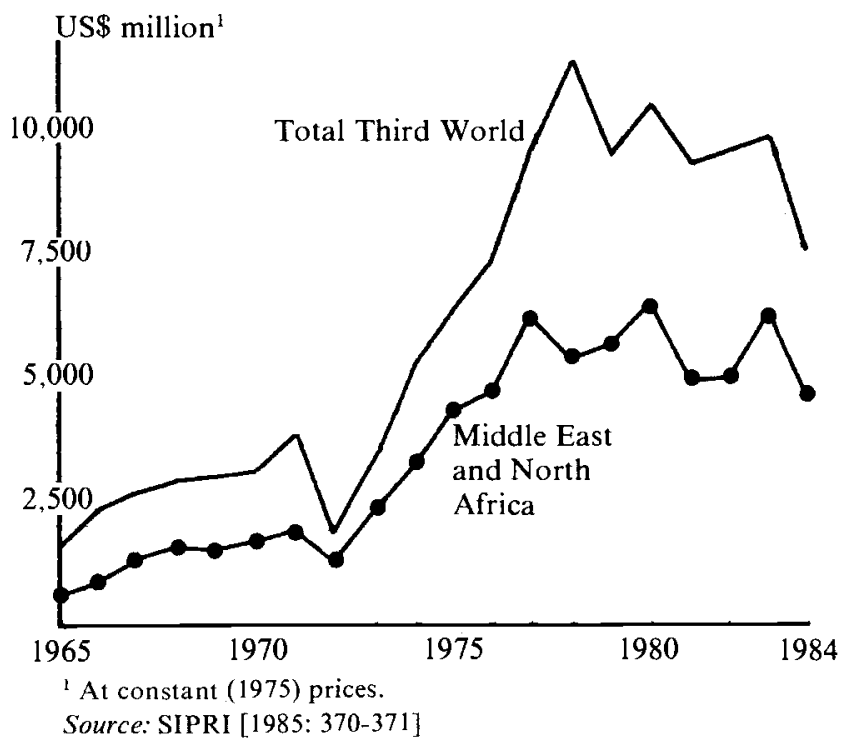

Whilst the industrial North faces the prospect of a potential nuclear holocaust, much of the developing South is already engulfed in violence: both the direct violence of armed conflict, and the structural violence of repression and underdevelopment. Some of the 


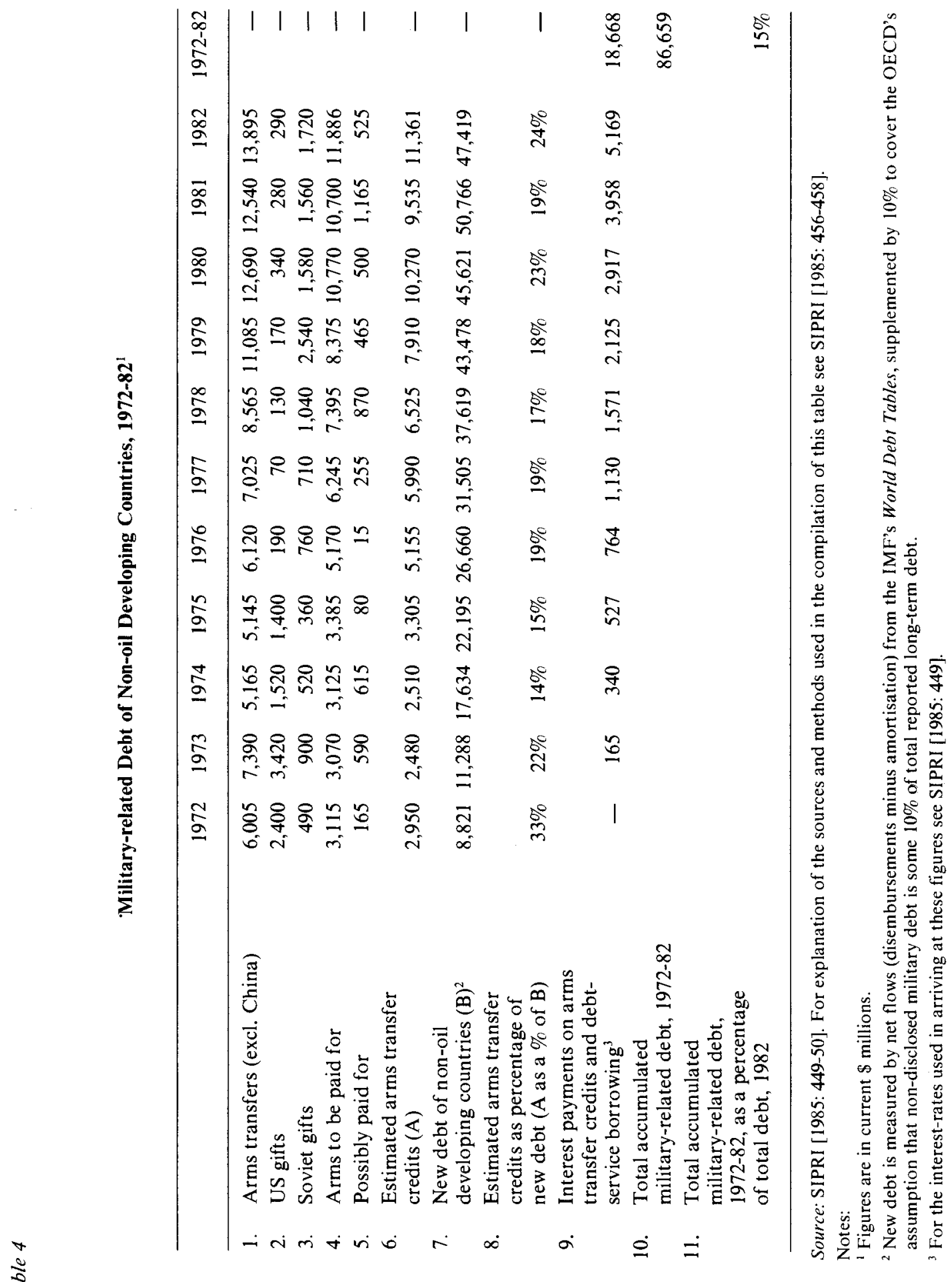


wars fought in the South have been as destructive as any fought on this planet. Their casualties (since World War II) number in the tens of millions, not to mention those who have been wounded, fled the war zones or become victims of hunger and disease. Two things have greatly increased the devastation. First, the social character of many conflicts, the fact that they are not merely conventional wars between states but are rooted in much broader social upheavals - as in Central America, Southern Africa, the Lebanon or Afghanistan. And secondly, the fact that advances in military technology have introduced ever more powerful ways of killing, maiming and destroying. Chemical weapons and other ways of modifying the natural environment have already been used in conflicts in the Third World - by the US, for example, in Vietnam, by Iraq against Iran and perhaps by the USSR in Afghanistan. At the same time the conventional munitions developed by the arms manufacturers - cluster and fragmentation bombs, fuel-air explosives etc - and increasingly utilised in the Third World, have become so destructive that they are calling in question the established boundaries between nuclear and conventional warfare.

Thus it is no longer possible (if it ever was) to make sharp moral and empirical distinctions between the risk of nuclear mass destruction in the North and the appalling realities of warfare and underdevelopment in the developing South. Any inventory one might make of those - including children - who are most at risk from poverty, disease and natural disaster would overlap with those most at risk from military violence. The target-groups of poverty-focused development assistance have too frequently also been the targets of weapons. There are direct and indirect causal relationships between armed conflict, economic deterioration and even natural disasters (like the droughts in the Horn of Africa and Southern Africa). It is difficult to generalise about such interconnections, since they vary so much from situation to situation. Nevertheless, they deserve more serious scrutiny by development researchers and practitioners than they usually receive.

Glimmers of hope can be extracted from the resumption of arms talks and the impending ReaganGorbachev Summit. In the longer run the relative economic decline of the superpowers and the disagreement developing between the USA and Western Europe over issues such as the Strategic Defence Initiative, economic relations with Eastern Europe, industrial protection and intervention in the Third World could open up opportunities for change as well as give rise to fresh dangers.

As for the developing countries themselves, their military expenditures have never (in spite of rapid growth) constituted more than a small fraction of the global total (see Table 2). Some comfort can be extracted from the fact that they have now ceased to rise. In any case, there has always been much diversity, with some countries (many of them oil exporters) devoting large shares of government revenue and GNP to military purposes and others relatively little. The bulk of arms purchases have been heavily concentrated among a relatively small number of Third World recipients, many of them in the Middle East (Table 3). The determinants of arms transfers are too complex to be explained purely in terms of EastWest relations or the 'pushing' of arms by the suppliers (even though both are crucial).

\section{Table 5}

African imports of major weapons, 1970-83: by economic and geographical groups

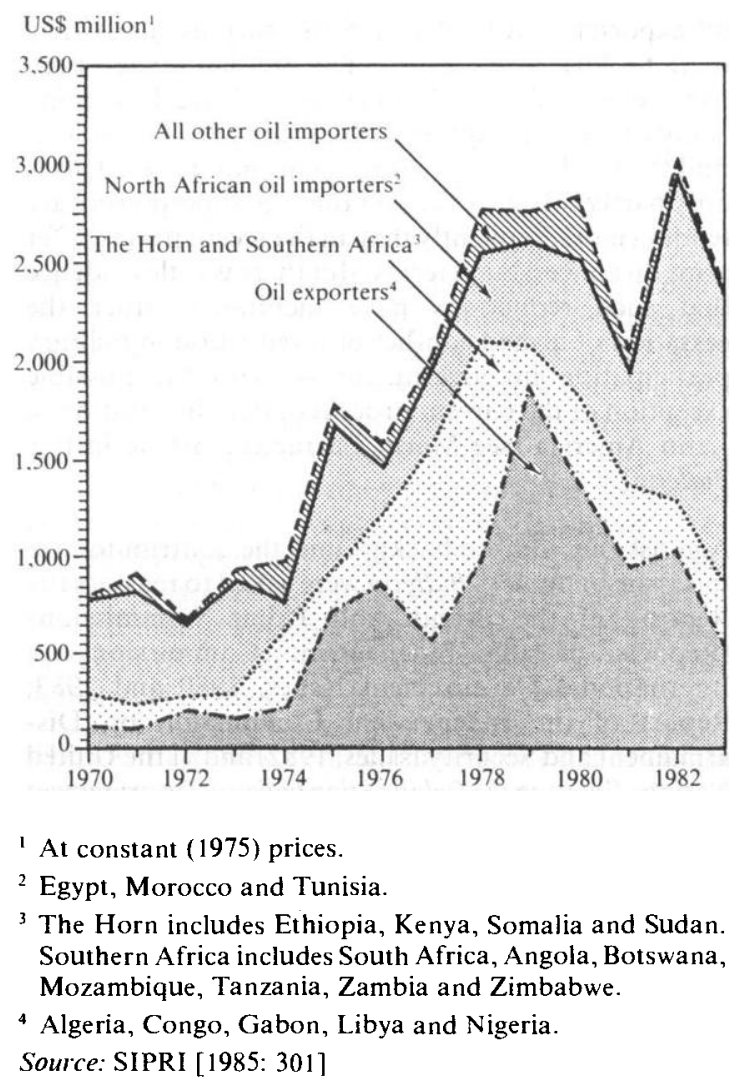

An illustration of this complexity is provided in Table 5 which demonstrates how at different times since 1970 the major factors influencing the transfer of arms to Africa have varied, including the recycling of 
oil revenues by African members of OPEC; the conflicts in the Horn and Southern Africa; and the recent conclusion by the United States of agreements with strategically placed countries in North Africa and the Horn under which arms have been supplied in exchange for military facilities for the rapid deployment force (US Central Command). Another factor which the Table does not, however, bring out is the fact that the Soviet Union was the continent's major supplier for much of the 1970s [see Luckham 1985a].

The flow of arms to the Third World contracted sharply in the first part of the 1980s and there is little evidence that it is likely to resume its previous rapid growth. It is sometimes argued that this is because the arms market is now saturated after a period in which several developing countries simultaneously replenished their armouries with new generations of sophisticated weapons. More important, however, is the impact of recession and international debt. Many oil exporters have exhausted the surplus funds they used to buy arms; and some are no longer even considered credit-worthy borrowers. Other developing countries (excepting some NICs) are even less able to find the hard currency for weapons purchases. This is only partly offset by the fact that the superpowers are tending more frequently than in the recent past to offer arms on concessional terms. But there is little evidence that such reductions have facilitated either the cessation of armed conflict or a reduction in military participation in government - with the possible exception of the current process of demilitarisation in Latin America [see Mario Carranza's article in this Bulletin].

Against this sombre background the contributors to this issue of the IDS Bulletin were asked to reassess the Reports of the Brandt "and Palme Commissions (Reports of the Independent Commission on International Development Issues, 1980 and 1983; Report of the Independent Commission on Disarmament and Security Issues, 1982) and of the United Nations Study on the Relationship between Disarmament and Development (the Thorsson Report: United Nations 1981). All four studies were made during a period of transition in the global economy and the Cold War (1979-83). Despite differences of emphasis they all advocate an integrated global approach to world economic and military problems, the restructuring of North-South economic relationships, strengthening of detente and reductions in the allocation of resources for military purposes. They have sometimes been criticised for not taking their analysis far enough or for lack of political realism [see for example IDS 1981, Luckham $1985 \mathrm{~b}$ and Holm below). But it cannot be disputed that the reports represented a crucial series of initiatives by influential groups operating inside the international policymaking community, at a critical juncture in history.

Why, then, have they had so little impact on policy and still less on the march of events? Is it because of inconsistencies in the arguments of the reports themselves? Did they give enough attention to the political changes that might be required - such as dismantling the system of blocs, reorganising the UN or establishing a political constituency for disarmament in the Third World as well as in Europe and North America? Why has international discussion tended to isolate the economic from the strategic/ political dimensions of the present global crisis? Why do policy-makers in the North seem to show so little interest in disarmament and development? Is there a legitimate basis for Third World suspicion of Northern proposals to limit arms transfers and military spending in the South? Or is the lack of progress merely one consequence among many of the overall deterioration in the international situation?

Our contributors were also asked to address themselves to how disarmament and development could be put back on the international agenda. Should each issue be dealt with separately on its own merits, or is a coordinated approach required? What can be learnt from the successes and failures of earlier proposals? What role can Third World count ries play? How might their demands be linked to European proposals for dealignment from the blocs? Do the new negotiations between the superpowers create the space for other initiatives to reduce international tension? How might the forthcoming UN Special Conference on Disarmament and Development be used to launch a new series of initiatives?

Willy Brandt and Inga Thorsson argue strongly that most of the findings of their respective reports remain valid today. Failing to implement them - and instead applying 'considerable skills ... to patch up holes 'as Brandt put it - is the fault of the superpowers. A similar analysis is made by Shridath Ramphal, a member of both the Brandt and the Palme Commissions, who adds that the winds of history were already turning against detente and the construction of a New International Economic Order when the reports were put before the public. All three, however, believe that the superpowers can still be influenced by political pressures and by appeals to their enlightened self interest. They support a multilateral approach, calling for a strengthening of the decision-making and peace-keeping machinery of the United Nations. And they argue that both disarmament and development remain very much on the UN agenda, pointing out that the debate over their relationship will continue - though perhaps in a lower key — at the 1986 UN Special Conference. 
Next we come to two outside assessments. The first, by Hans-Henrik Holm is a useful summary of the reports and a biting critique. The reports are faulted on two major grounds. First, for their tendency to assume that the world's major problems could be solved by transfers of resources from rich countries to poor and from military to non-military uses, without adequate empirical demonstration of the intervening links. Second, for their lack of political realism: their failure to translate multilateral measures based on long term common interests into policies for change that national governments, especially those of the major military powers, could implement. In this he reinforces some of the criticisms made of the Brandt Report in a previous issue of the Bulletin, 'Britain on Brandt' [IDS 1981, especially the article by Vaitsos]: that the practical procedures for implementing its proposals were not well enough specified in technical terms, were at variance with established global power relations and assumed a mutuality of interest between North and South which the mere fact of their interdependence did not necessarily create.

Some readers might think these criticisms rather harsh. The difficulties of moving from analysis to policy and from policy to practice are notorious. Unlike the angel of history, the angel of policy sets his face so resolutely forward that he does not see the storms catching him from behind. The angel of politics (if there is one) is so busy trimming his wings to the winds that he cares not where they take him until he falls.

There is, however, no lack of concrete proposals in the reports which, after all, were the work of men and women who possess between them vast collective experience in the making of policy. In his article Willy Brandt suggests that Europe should play a more active role in bringing the superpowers to the negotiating table and in reactivating proposals for a 'global discussion' of international economic issues. Shridath Ramphal argues that the non-nuclear countries can ensure that alternative voices are heard on disarmament through a variety of international channels, including the Commonwealth. Inga Thorsson emphasises the importance of domestic and international political processes, since governments tend not to take action unless obliged to by their citizens. She also extracts some encouragement from the economic difficulties facing the industrial North: that this could force a reassessment of the costs of the arms race by governments in both major military blocs.

But, these are piecemeal suggestions. They do not directly address the deep structures of the arms race; nor (except Thorsson) do they give enough attention to political processes through which it could be reversed. A good starting point for understanding the latter is provided by Chris Smith and Mac Graham, who argue that the disarmament and development debate is itself the outcome of a distinct political process played out within the inherent limitations of the UN system. It first emerged in the 1960 s as a direct reaction to the manner in which the superpowers pushed disarmament to the sidelines in favour of arms control based on bilateral negotiations (or in a few instances talks among a limited circle of nucleararmed states). It acquired its own political constituencies among the neutral countries in Europe and the non-aligned countries in the Third World. It gathered momentum during the period of detente, climaxing at the 1978 and 1982 UN Special Sessions on Disarmament. But like detente it was undermined by the renewal of the arms race.

The arms race in turn has been driven by the sectoral momentum of the military product cycle combined with shifts in international power politics. One might almost talk of a political trade cycle, clearly visible in the movements of US military spending depicted in Table 1. New generations of weapons systems have been developed and brought into service. This has encouraged the major military powers to extend the frontiers of the Cold War into space and into the Third World. It has also brought even bilateral talks to a virtual halt.

Such arguments are taken still further in a sweeping critique by Ferenc Miszlivetz of the way disarmament has been subverted by the bipolar logic of the arms race. There has developed a symmetry between civil society and the military sector, cemented by a promiscuous network of military interests and alliances and legitimised by the concept of security: a characterisation he regards as being equally (but differently) valid for the socialist countries of the East as for the capitalist countries of the West. It is in this context that he suggests that military technology may be the most crucial legacy of the North to the South, almost inevitably shaping the process of development.

The way East-West conflicts have been extended to the South, contributing to the latter's militarisation, is also taken up by Tamas Szentes. His perspective is perhaps less Manichean, and he argues that the distinctions between North and South, East and West are simplifications that sometimes get in the way of our understanding of the underlying relationships. What is particularly striking is his argument that the Cold War has encouraged the transfer of inappropriate socialist as well as capitalist development models: the former failing, indeed, to reflect crucial changes in economic management that have taken place in Eastern Europe since the earlier Cold War period.

The danger, however, with arguments that the Cold War and inequalities between North and South are so 
deeply entrenched in the international system that they will not respond to policy reforms such as those proposed in the Brandt, Palme and Thorsson reports, is that they can easily induce apathy: roll on the holocaust! Or they can lead, full circle, to a cynical conservatism: power politics is all that counts and the devil take the hindmost! Any strategy for change must be able to identify the fault-lines as well as the structures, the virtuous as well as the vicious circles.

This in turn, requires a better understanding of empirical relationships. Does military spending in fact entrench underdevelopment? How easily can resources be transferred from military to non-military uses? To what extent and through what mechanisms is militarisation in the South linked to the arms race in the North? Will the resources released by cuts in military spending be used for productive purposes rather than conspicuous consumption? Is there an adequate political case for linking disarmament to development; or is connecting them likely to obstruct progress on both?

A major obstacle to establishing the empirical connections is the absence of reliable data on the military sector, This situation is examined by Nicole Ball, who proposes a number of ways in which it could be remedied, including the use of national military budgets to supplement the information available in the standard international statistical sources. Both in the industrial and the developing countries governments tend to conceal their security expenditures from public scrutiny. The data are seldom disaggregated in a manner that enables researchers to analyse the most crucial variables, for example the foreign exchange component of military spending. As Dudley Seers once pointed out, this is a difficulty with which development researchers are already familiar. Many of the standard macroeconomic indicators - national accounts, government budgets, balance of payments - presuppose a Keynesian model of advanced industrial economies and are of less use in understanding the dynamics of developing economies [Seers 1983].

Deger and Smith also argue for more careful analysis of the variety of channels through which military spending can affect the development process. Their own econometric studies (some of which are cited in the UN report) suggest that defence spending reduces growth through its adverse effects on saving, investment and foreign exchange, as well as on human capital and absorbtive capacity. These more than compensate for the positive effects in terms of the mobilisation of resources and possible technological spin-offs.

A warning note is, however, sounded by David Evans who used more recent evidence based on the World
Bank's 1983 World Development Report, to demonstrate that the positive effects of military spending may (in the 1970s) have outweighed their diversion of surpluses from productive investment. The title of his article, 'Back to Benoit?', referring to the original studies by Emile Benoit which had uncovered positive relationships between military spending and growth, is perhaps misleading. For the real message is that more specific analysis is required, with regard to timeperiods, regions and above all the particular models of development being implemented and their political conditions. Strong government and high military spending (though the two do not necessarily go together) could well facilitate certain types of externally-oriented capitalist development [Luckham 1977]. The same could well be true of some models of socialist development, at least if the frequency of leftwing military regimes ('garrison socialism') is anything to go by.

This line of argument is reinforced by Eboe Hutchful in regard to Africa, and by John Ohiorhenuan in his case study of Nigeria. They both suggest that structural adjustment programmes of the type proposed by the Berg Report in Africa (discussed in IDS 1983) frequently impose heavy social costs and result in political instability. Authoritarian government is a necessary condition for the particular type of 'crisis management' undertaken under the supervision of the IMF and World Bank. Ohiorhenuan argues that this helps explain the heavily repressive policies of the recently deposed Nigerian military government; although even the latter never concluded a formal agreement with the IMF, because it believed the political costs of devaluation to be too high.

So can it still be argued that disarmament and the reallocation of resources from military purposes are in Third World interests? The response to this question falls into two parts, depending on whether one is referring to disarmament in the industrial North or in the Third World. The latter, as Eboe Hutchful shows, is problematic to say the least, African countries are still on the whole lightly armed by global standards, in spite of two decades of rapid growth in their military spending and arms purchases. Their governments have legitimate security concerns, including aggression from South Africa and repeated military intervention by external powers. Even if there were to be major resource transfers from the industrial North these would not by themselves overcome underdevelopment. Development and the removal of the basic injustices which cause conflict are the first priorities on the African agenda; and disarmament is only relevant to the extent that it can be demonstrated - and not simply assumed - that it advances them. 
Mario Carranza is less doubtful of the relevance of demilitarisation to Latin America. A number of South American countries have recently transferred power from military to civilian hands, as well as cut their military spending. The so-called 'Brazilian miracle' no longer looks like such a good advertisement for military rule as it did some years ago; still less does the catastrophic economic situation presided over by the Chilean and the former Argentinian juntas. In Central America, armed conflict and US intervention are unequivocally the main causes both of military expenditure increases and economic deterioration. There is little here to support the argument that there is any fixed relationship between strong government and development, even along market-oriented World Bank/IMF lines [see Diaz Alejandro 1983, who introduces a similar note of scepticism].

One reason for divergence between Carranza and Hutchful may be the latter's somewhat narrow definition of disarmament in terms of nuclear arms control in the North and cuts in military budgets in the South: a combination which has admittedly tended to result in social transformation in the South becoming mortgaged to the preservation of the nuclear balance between East and West. A broader conceptualisation of disarmament in terms of transformations in the social and economic relationships which underpin both the arms race and the international division of labour would not be open to the same objections - although it might become correspondingly more difficult to specify empirically.

Nevertheless, Hutchful believes a good case can be made for a 'nuclear free zone' Africa. He doubts, however, whether African countries could negotiate - still less enforce - such a zone in the present situation of confrontation between the superpowers. Carranza reviews Latin America's rather more extensive experience of regional arms limitation, including the 1967 Treaty of Tlateloco declaring Latin America a nuclear-weapons-free zone, and the 1974 Ayacucho Declaration on regional conflict-resolution and arms limitation. The former, however, has been undermined by the proliferation of 'civilian' nuclear technology; and the latter has had relatively little effect on regional arms races. Nevertheless such agreements have symbolic importance, illustrated by the conclusion of a five country agreement to declare the Pacific a nuclear-free zone, in August 1985 (shortly after the sabotage of the Rainbow Warrior).

Regional security and arms limitation agreements such as these were a major recommendation of the Palme Report. But Third World countries are bound to have reservations about limitating their own armament whilst the superpowers still regard themselves as entitled to use force in the Third World and preserve their monopoly over negotiations concerning the central strategic balance. Similarly the inability of the major world powers to restrain nuclear competition among themselves has emerged as one of the major obstacles to agreement about nuclear nonproliferation, as at the 1985 NPT Review Conference.

So can governments in the North be persuaded it is in their interest too, to curb military spending and disengage from the arms race? As Inga Thorsson points out, if the linkages between military spending and economic stagnation can be empirically demonstrated, this strengthens the political case for disarmament. It also suggests the case for limiting arms sales, to the extent that the latter are necessary for the maintenance of prevailing specialisations in military production. Deger and Smith's analysis of military spending in the developing countries follows up earlier studies by Smith (1977) which suggest that in the advanced capitalist countries of the OECD military expenditure in the post World War II period has been negatively related to investment and, through investment, to growth. The economies with the highest military spending relative to national product (the USA, the UK and France) have invested less and have grown slower than those with historically lower military burdens (notably West Germany and Japan). Raphael Kaplinsky examines the longer term factors that account for this uneven pattern of industrial accumulation, suggesting that military spending (contrary to what is popularly assumed) has had a net negative effect on technological progress, both in the USA and in the UK.

But do these considerations still hold good in a period of recession, when military cuts could bring loss of jobs and adverse multiplier effects? The large military increases of the early 1980s, it is sometimes maintained, have helped restore growth in the US economy. Whether the recovery is sustainable is still not clear. Perhaps alternative strategies for economic recovery, based on civilian investment would have lower opportunity costs and create more employment. Yet as in the 1930s [see Kalecki 1943] military spending has been a politically more attractive option during a period of gathering domestic and international tension; all the more so when full employment has ceased to be the touchstone of economic policy.

Nevertheless, if alternative options are to be put forward, realistic strategies for the conversion of military resources to civilian uses are essential. As regards the UK, Kaplinsky points out successful large scale resource transfers have been achieved on at least three occasions since World War II, both from and (over the past six years) to the military sector. The most systematic attempt to date to spell out a strategy 
for conversion in an advanced industrial economy is Inga Thorsson's report to the Swedish government. In Pursuit of Disarmament [Government of Sweden 1984]. reviewed in this Bulletin by Sue Willett. The special structural characteristics of the military industries - their orientation toward product rather than process innovation ('gold-plating'). cost escalation. their cosy relationship with the defence establishment - create technical problems which Thorsson nevertheless argues are soluble. Less amenable to technical solutions, as Willett points out. are the political issues: to elaborate a programme of military reductions for the UK could be construed as a challenge to NATO. If conversion implies less reliance on arms sales. cuts in naval and 'rapid deployment' forces and reduced military commitments 'outside the NATO area'. it also requires changed relationships with the Third World. In a world in which the costs of economic recovery have all too frequently been passed on to the Third World - through high interest rates, aid cuts. the economic and political conditionalities built into aid programmes and interventionist foreign policies - this may present the greatest challenge of all.

\section{References}

The Commission on Security and Economic Assistance. 1983. A Reporl to the Secreiary of Stare. Washington DC

Diaz Alejandro. C. F., 1983. 'Open economy closed polity? in D. Tussie (ed). Lain Antrica and the World Economy. Gower, London

Government of Sweden. 1984. In Pmsuil of Disarmoncm. Comersion from Milinary o Civilian Producrion in Siveden Vols IA and IB. Report by the Spccial Expcrt: Ingal Thorsson. Stockholm

Hackett. General Sir John. et al. 1978. The Third World War. Sphere Books. London

- 1983. The Third Workd War: he Unold Srory. Sidgwick and Jackson. London

IDS. 1981. 'Britain on Brandt'. IDS Bulle'im, vol 12 no 2

-1983. Accelerated Development in Silb-Saharan Africa. IDS Bnllerin. sol 14 no 1 -1985a. 'Slowdown or Crisis'? Restructuring in the 1980s'. IDS Bullenin. vol $16 \mathrm{nol}$

-1985b. 'The Western Hemisphere in the World Crisis'. ID.S Bullemin. vol 16 no 2

Kalccki. Michal. 1943. 'The political aspects of full cmployment" reprinted in The lasi Phase in he Transfornolion of Capilalism. Monthly Review Press. New York. 1972

Leitenberg. Milton. 1985. 'The impact of the worldwide confrontation of the grcat powers: aspects of military intervention and the projection of military power in $\mathrm{G}$. Fischer (cd). Armamemls - Derelopments - Hmwon Righls - Disarmamem. Faculté de Droit. Université Paris V

L.uckham. Robin. 1977. 'Militarism and international dependence' in R. Jolly (ed). Disamament and World Developnem. Pergamon. Oxford

- 1985a. 'Militarisation in Africa' in SIPRI op:cil. ch 9

-1985b. "The arms race and the Ncw International Anarchy". in G. Fischer (ed). op.cil.

Nincic. Miroslav. 1985. How War Might Spread to Europ'. Taylor and Francis for SIPRI. London

Report of the Independent Commission on International Development Issues (the Brandt Report). 1980. NorlhSounh: A Progranme for Survival. Pan Books. London

- 1983. Common Crisis: North-Somh: Cooperation for World Recoverr. Pan Books. London

Report of the Independent Commission on Disarmament and Security Issues (the Palme Report). 1982. Common Securily: A Programme for Disarnamen. Pan Books. London

Seers. Dudley. 1983. 'Statistical needs' in The Political Econony of Nalionalism. Oxford University Press. Oxford. Ch 9

Smith. Ron. 1977. 'Military cxpenditures and capitalism'. Cambridge Jommal of Economics. March

Stockholm International Peace Rescarch Institute (SIPRI). 1985. World Armam'ms and Disamamem; SIJR/ Y'arhook. 198.5. Taylor and Francis for SIPRI. London

United Nations. 1981. Sundy on the Relanionship belueen Disarmamem and Derelopment (the Thorsson Report). Report of the Secretary-Generall. New York

World Bank. 1984. World Developmen Repor. 1984. Oxford University Press for the World Bank 